\title{
Geographical variability of relationships among black carbon from wildfires, climate and vegetation in Africa
}

\author{
Shota Ishii ${ }^{1, *}$, Hisashi Sato ${ }^{2}$, Takeshi Yamazaki ${ }^{1}$ \\ ${ }^{1}$ Graduate School of Science, Tohoku University, 6-3, Aoba, Aramaki, Aoba, Sendai, Miyagi 980-8578, Japan \\ ${ }^{2}$ Graduate School of Environmental Studies, Nagoya University, D2-1(510) Furo-cho, Chikusa-ku, Nagoya-city, \\ Aichi 464-8601, Japan
}

\begin{abstract}
Frequent wildfires emit large amounts of black carbon $(B C)$ into the atmosphere in the semiarid regions of the African continent. This atmospheric BC efficiently absorbs shortwave radiation and thus modifies the climate system on a regional scale. Therefore, it is essential to understand how geographical distribution patterns of $\mathrm{BC}$ emissions are controlled by climate and vegetation in these regions. We applied a principal component analysis (PCA) to the correlations between dry season $\mathrm{BC}$ emissions observed by satellite and climate variables during the vegetation growing and dry seasons, and to correlations between $\mathrm{BC}$ and the leaf area index during the growing season, as independent values. We analysed the burned fraction (BF) in the same way, but its factor loadings did not differ significantly from those of BC in sign or magnitude. During the growing season, the response pattern of vegetation productivity (an index of wildfire fuel loading) to climate variables explained $57.5 \%$ of the regional variability in $\mathrm{BC}$ emissions. This vegetation productivity was more closely correlated with the geographical distribution patterns of BC emission than climate variables such as temperature during the dry season. The response pattern of vegetation productivity to climate during the vegetation growing season was roughly determined by vegetation parameters such as biome type and tree cover, which are heterogeneously distributed in Africa. Therefore, regional BC emission patterns would differ even if climate change occurred uniformly throughout semi-arid Africa.
\end{abstract}

KEY WORDS: Black carbon $\cdot$ Wildfire $\cdot$ Africa $\cdot$ Emission factor $\cdot$ Regional variation

\section{INTRODUCTION}

In semi-arid regions of Africa, wildfires, which occur frequently during the dry season, strongly constrain the structure, dynamics and distribution of vegetation (Higgins et al. 2000, 2007, Sankaran et al. 2004, 2005, Bond et al. 2005) and emit large amounts of black carbon $(\mathrm{BC})$ to the atmosphere (Bond et al. 2004). Atmospheric BC can change the climatic system by absorbing shortwave radiation and thereby decreasing downward shortwave radiation to the land surface (Ramanathan \& Carmichael 2008). Ka-

*Email: ishii@wind.gp.tohoku.ac.jp wase et al. (2011) reported that the reduction in net radiation to the land surface due to atmospheric $\mathrm{BC}$, by suppressing evapotranspiration, caused a decreasing trend in precipitation in tropical Africa in the 20th century. The recycle ratio, defined as the ratio of evapotranspiration from the land surface that falls as local precipitation to the total precipitation, is high in Africa. Van der Ent et al. (2010) estimated that the recycle ratio is 0.49 in the global region $\left(37^{\circ} \mathrm{N}-34^{\circ} \mathrm{S}, 17^{\circ} \mathrm{W}-59^{\circ} \mathrm{E}\right)$ that includes the African continent. Therefore, any decrease or increase in atmospheric BC is likely to have a significant impact

(C) The authors 2013. Open Access under Creative Commons by Attribution Licence. Use, distribution and reproduction are unrestricted. Authors and original publication must be credited. 
on precipitation over the African continent. Because vegetation productivity determines the fuel production rate (Lehsten et al. 2009), an investigation of the relationships among fire, climate and vegetation abundance is necessary to understand climate system dynamics in Africa.

The geographical pattern of wildfire frequency and intensity is primarily determined by climate, fuel loading and the moisture content of the fuel (Cooke et al. 1996, Bowman et al. 2009). The pattern is also affected by the vegetation type (Dwyer et al. 2000), lightning frequency, human population density (Keeley et al. 1999), land use (Russell-Smith et al. 2007) and tree cover (Archibald et al. 2009). However, the integration of these factors to generate the observed geographical pattern of wildfires has yet to be adequately evaluated quantitatively.

Remote sensing studies of the Sahel have suggested that interannual perturbations in indices of vegetation greenness such as the normalised difference vegetation index (NDVI) and the leaf area index (LAI) are primarily controlled by precipitation (Anyamba \& Tucker 2005, Hickler et al. 2005). On the African continent generally, field studies suggest that precipitation is the primary determinant of plant species composition and plant production (Gonzalez 2001, MacGregor \& O'Connor 2002, Lwanga 2003). Besides precipitation, air temperature and solar radiation intensity also affect vegetation productivity (Allen et al. 2010).

The aim of this study was to estimate the factors that influence the occurrence of wildfires and the geographical distribution pattern of BC emissions (e.g. vegetation type, lightning frequency, human population density, land use and tree cover) in semiarid Africa. However, we were unable to directly analyse the correlations between the BC emission and these factors because there are no long-term time series data for, e.g. vegetation type and tree cover. Thus, the significant differences in the geographical distribution pattern of the 6 correlation coefficients, namely BC-precipitation (growing season), BC-temperature (growing, dry season), BCcloud cover (growing, dry season) and BC-LAI (growing season) (i.e. variations in the 6 correlation coefficients across semi-arid Africa), were estimated by performing a principal component analysis (PCA). Meaningful comparisons of the geographical distribution patterns were analysed using the variations in these 6 correlation coefficients across semi-arid Africa (i.e. the principal component scores). Finally, the factors that influence the occurrence of wildfires and the $\mathrm{BC}$ emission geographical distribution pat- tern were estimated by comparing the geographical distribution of the factors estimated from previous work and the analysed principal component (PC) scores in this study.

\section{DATA AND METHODS}

We used existing data sets for our analysis (Table 1). We converted the spatial resolution of the LAI and tree cover data to a $0.5^{\circ} \times 0.5^{\circ}$ grid resolution to match the resolution of the other datasets by simple averaging over each grid cell domain. The $\mathrm{BC}$ is related to the burned fraction $(\mathrm{BF})$ - which was calculated by dividing the yearly burned area in a grid cell by the total area of that grid cell - and to incomplete fuel combustion (Schmidt et al. 2001). The fire fuel comprises the hot volatile vapour-phase products of the thermal decomposition of vegetation. These vapours and their cracking products undergo flaming combustion. However, in competition with this, they can also undergo condensation and charring to powdery soot particles. These soot particles may combust or be swept into the air away from the fire to become aerosol BC. Thus, the distribution of hot volatiles between flaming combustion and thermo-condensation, and between aromatisation and soot formation, determines the incomplete combustion ratio, which is a different quantity from the $\mathrm{BF}$. Therefore, the determinants of BC are more complicated than those of BF.

As the study area, we selected part of sub-Saharan Africa $\left(3-12^{\circ} \mathrm{N}, 12^{\circ} \mathrm{W}-34^{\circ} \mathrm{E}\right.$ and $15-5^{\circ} \mathrm{S}, 24^{\circ} \mathrm{W}-$ $39^{\circ} \mathrm{E}$ ) where a large amount of BC is emitted every year. In this study, we define the dry season, which corresponds to the fire season in Africa (Dwyer et al. 2000), as the months of December to February (DJF) in the northern hemisphere and July to September (JAS) in the southern hemisphere. We define the growing season as the months of April to October in the northern hemisphere and the months of November to May in the southern hemisphere. We excluded from our analysis data for March and November (northern hemisphere) and those for June and October (southern hemisphere), because in those months the distinction between the growing and dry seasons is unclear. The growing season was defined so as to have no overlap with the dry season, and to include the month in which the LAI reached its maximum value in that hemisphere.

We divided our study area into 40 large $\left(3.0^{\circ} \times 3.0^{\circ}\right)$ grid cells (Fig. 1). Each large grid cell was composed of 36 small $\left(0.5^{\circ} \times 0.5^{\circ}\right)$ grid cells. A large grid cell 
Table 1. Datasets used for analysis. LAI: leaf area index; BC: black carbon; BF: burned fraction

\begin{tabular}{|c|c|c|c|c|c|}
\hline Variable & Data product & Data period & $\begin{array}{l}\text { Product } \\
\text { resolution }\end{array}$ & $\begin{array}{c}\text { Time } \\
\text { interval }\end{array}$ & Reference \\
\hline $\begin{array}{l}\text { Temperature, } \\
\text { precipitation, } \\
\text { cloud cover }\end{array}$ & $\begin{array}{l}\text { Climatic Research Unit } \\
\text { (CRU) TS3.1 }\end{array}$ & $1997-2008$ & $0.5^{\circ} \times 0.5^{\circ}$ & Month & Mitchell \& Jones (2005) \\
\hline LAI & MODIS & $2001-2008$ & $0.25^{\circ} \times 0.25^{\circ}$ & Month & $\begin{array}{l}\text { MOD15A2 (Land Processes } \\
\text { Distributed Active Archive Center, } \\
\text { http://lpdaac.usgs.gov) }\end{array}$ \\
\hline $\mathrm{BC}, \mathrm{BF}$ & $\begin{array}{l}\text { Global Fire Emissions } \\
\text { Database version } 3\end{array}$ & $1997-2008$ & $0.5^{\circ} \times 0.5^{\circ}$ & Month & Giglio et al. (2010) \\
\hline Biome & $\begin{array}{l}\text { The International Satellite } \\
\text { Land Surface Climatology } \\
\text { Project (ISLSCP) Initiative II } \\
\text { Data Collection }\end{array}$ & - & $0.5^{\circ} \times 0.5^{\circ}$ & - & Turner et al. (2006) \\
\hline Tree cover & $\begin{array}{l}\text { AVHRR Continuous Fields } \\
\text { Tree Cover Product }\end{array}$ & - & $1 / 60^{\circ}$ (= $\left.1 \mathrm{~min}\right)$ & - & DeFries et al. (2000) \\
\hline
\end{tabular}

was included in the analysis if more than half of the contained small grid cells had mean BC emissions (averaged over the years 1997-2008; Fig. 1) $>0.05 \mathrm{~g} \mathrm{C} \mathrm{m}^{-2}$ during the dry season in the region in which the large grid cell was located. The selected grid cells clustered in 3 regions, which are referred to as Regions 1-3 hereafter (Fig. 1).

We analysed the effect of climate variables during both the growing and dry seasons, and the effect of LAI during the growing season on $\mathrm{BC}$ emissions during the dry season and $\mathrm{BF}$. First, we averaged the $\mathrm{BC}, \mathrm{BF}$, air temperature and cloud cover during the dry season for each year and each large grid cell. We did not average precipitation during the dry season because its quantity was negligible. We used the normalised probability density of annual BC emissions in the large grid cells to calculate the correlation coefficients between BC and each climate variable. Wildfire consumes its fuel load, and thus it rarely occurs every year in the same small grid cell $\left(0.5^{\circ} \times 0.5^{\circ}\right)$. As a result, the probability density of annual BC emissions in a single grid cell is unlikely to have a normal distribution. The distribution of the probability density of annual BC emissions averaged in each large grid cell $\left(3.0^{\circ} \times 3.0^{\circ}\right)$, however, is
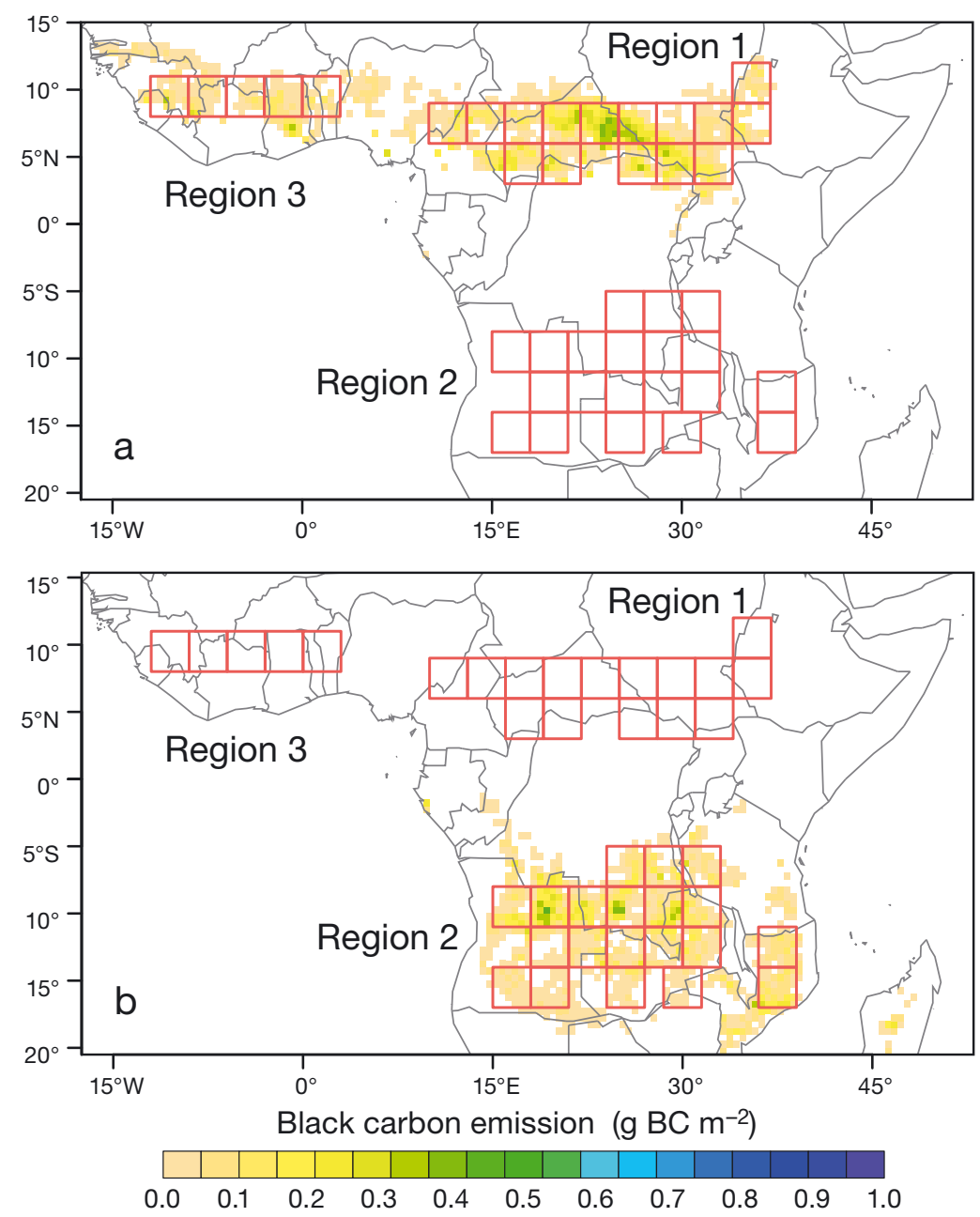

Fig. 1. Black carbon (BC) emissions during the dry season in the northern and southern hemispheres averaged over 1997-2008: (a) December to February and (b) July to September. Data are from the Global Fire Emissions Database v. 3 (see Table 1). Red squares: large grid cells $\left(3.0^{\circ} \times 3.0^{\circ}\right)$ in the 3 analysis regions 

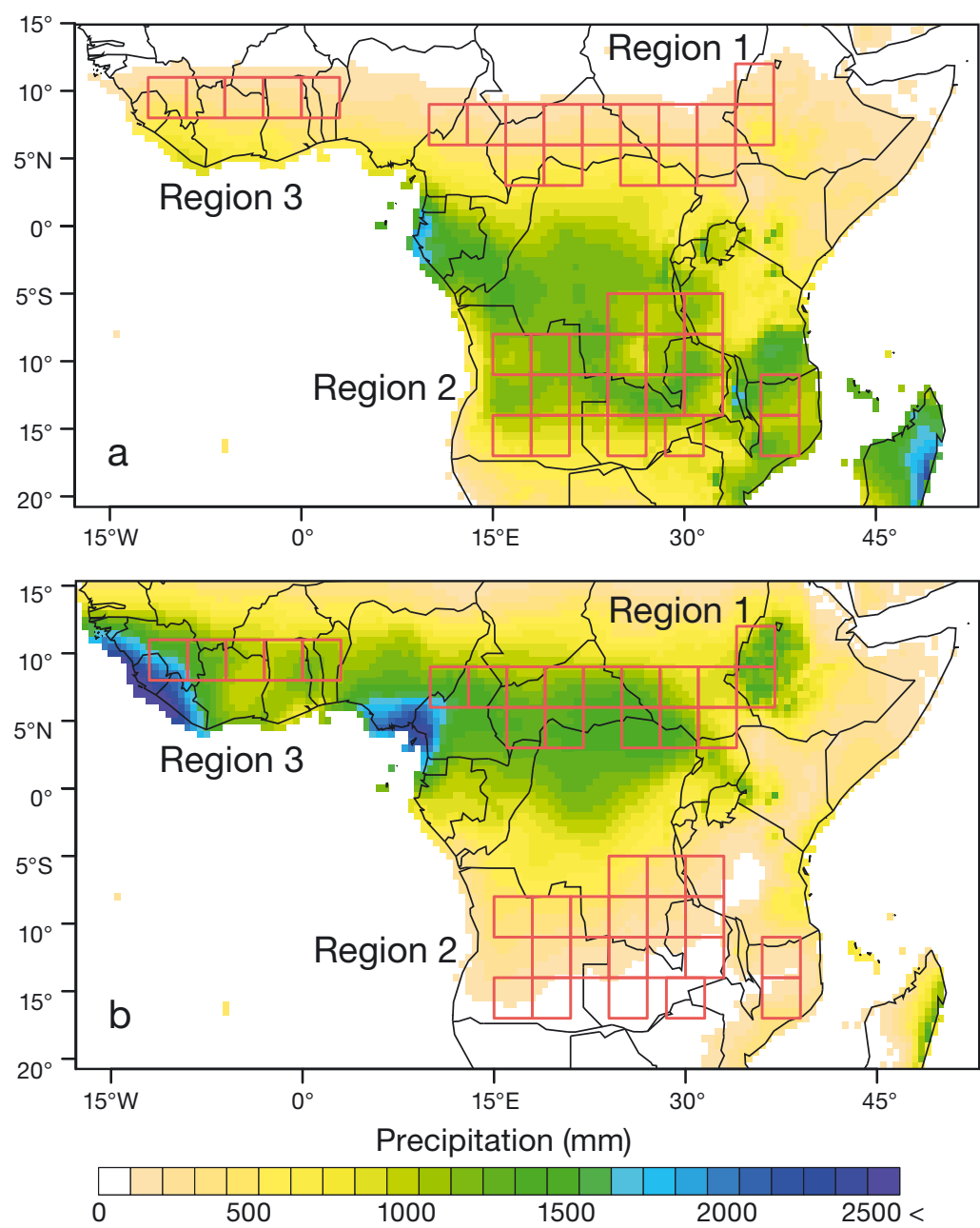

Fig. 2. Precipitation integrated over the 7 mo vegetation growing season in the northern and southern hemispheres, averaged over 1997-2008: (a) April to October and (b) November to May

likely to be closer to a normal distribution. If an even larger grid size were employed, the probability density distributions of $\mathrm{BC}$ would become even closer to a normal distribution, but the heterogeneity of climate variables within a grid cell would be obscured. Therefore, we used trial and error to determine that a grid size of $3.0^{\circ} \times 3.0^{\circ}$ gave the best balance in this trade-off.

We similarly averaged the climate variables, i.e. precipitation (Fig. 2), temperature and cloud cover, along with the LAI over the growing season of each year in each large grid cell. We did not average the $\mathrm{BC}$ emissions and $\mathrm{BF}$ during the growing season, when wildfires rarely occurred.

Normally distributed variables can be represented by their normalised deviations, which allow comparisons to be performed among regions. We calculated the normalised deviation of variable $A\left(A^{\prime}\right)$ as follows:

$$
A_{j}^{\prime}=\frac{A_{j}-\overline{A_{j}}}{\sigma_{j}}
$$

where $A_{j}, \bar{A}_{j}$, and $\sigma_{j}$ show the values for both the dry and growing season variable $A$ in grid cell $j$, the value of $A_{j}$ averaged over the analysis period and the standard deviation of $A_{j r}$ respectively; $j=1,2 \ldots n$, where $n$ is the total number of large grid cells in each region. We used Eq. (1) to obtain the normalised deviations of air temperature and cloud cover data during the dry and growing seasons, precipitation and LAI during the growing season only, and $\mathrm{BC}$ and $\mathrm{BF}$ during the dry season only.

We used the normalised deviations of the variables to calculate the correlation coefficients between $\mathrm{BC}$ and climate variables during the dry season (i.e. temperature and cloud cover), and between $\mathrm{BC}$ and climate variables during the growing season (i.e. precipitation, temperature, cloud cover and LAI). In the same way, we also calculated the correlation coefficients between $\mathrm{BF}$ and the climate variables during each season. We then used these correlation coefficients to perform PCA, which is a technique for extracting informative orthogonal linear combinations of variables. By this analysis, we extracted 'fire factors' that expressed the geographical distribution pattern of $\mathrm{BF}$ in relation to precipitation, temperature, cloud cover and LAI, and other factors that expressed the geographical distribution pattern of BC emissions in relation to those variables. We then compared the BF and $\mathrm{BC}$ results.

For the PCA, we used data sets composed of the independent variables $X_{\mathrm{j} 1}$ to $X_{\mathrm{j} 6}$ in each large grid cell $j$, where $X$ is the correlation coefficient between $\mathrm{BC}$ emissions (or BF) during the dry season and 1 of 6 variables (LAI [growing], precipitation [growing], temperature [growing], temperature [dry], cloud cover [growing], cloud cover [dry]) (Fig. 3). The data matrix $\boldsymbol{X}$ was $40 \times 6$ in size. The sample size (i.e. the number of grid cells) was 40 , and the number of independent variables (i.e. the correlation coefficient) was 6 . In this way, we converted this multidimensional data set to low-dimensional factors with the least information loss. The $p$-dimensional data set $\boldsymbol{X}_{j p}$ 
could be reduced to $k$ dimensions $(k \leq p)$ by linear combination with

$$
Z_{j k}=\sum_{p=1}^{6} W_{p k} X_{j p}
$$

where $\boldsymbol{W}_{\boldsymbol{p}}$ is a coefficient matrix (i.e. for the $k$ th PC). In PCA, the linear combination of variables that explains the maximum variance of a multidimensional data set is called the first PC (PC1); the second PC (PC2) is the linear combination of the variables oriented orthogonally to PC1 that explains the maximum residual variance. This procedure solves the equations $\left(\boldsymbol{V}-\lambda_{k} \boldsymbol{I}\right) \boldsymbol{w}_{k}=0$ for $\lambda_{k}$ (eigenvalues) and $\boldsymbol{w}_{k \prime}$ where $\boldsymbol{V}$ is the covariance matrix for $\boldsymbol{X}_{\boldsymbol{j} \boldsymbol{p}}$ and $\boldsymbol{w}_{k}$ is the vector of coefficients on the $k$ th PC for each variable. $\boldsymbol{I}$ is the unit matrix. The cross-covariance matrix $(\boldsymbol{V})$ of the correlation coefficient matrix of each region $\boldsymbol{X}_{j p}$ (the independent variable, i.e. the correlation coefficient, $p=1 \sim 6$ in each grid cell $j=1 \sim 40$ ) can be calculated as follows:

$\boldsymbol{V}=\left[\begin{array}{cccc}\frac{\sum_{j=1}^{40}\left(X_{j 1}-\overline{X_{1}}\right)^{2}}{40} & \frac{\sum_{j=1}^{40}\left(X_{j 1}-\overline{X_{1}}\right)\left(X_{j 2}-\overline{X_{2}}\right)}{40} & \cdots & \frac{\sum_{j=1}^{40}\left(X_{j 1}-\overline{X_{1}}\right)\left(X_{j 6}-\overline{X_{6}}\right)}{40} \\ \frac{\sum_{j=1}^{40}\left(X_{j 2}-\overline{X_{2}}\right)\left(X_{j 1}-\overline{X_{1}}\right)}{40} & \frac{\sum_{j=1}^{40}\left(X_{j 2}-\overline{X_{2}}\right)^{2}}{40} & & \cdot \\ \cdot & \cdot & \cdot & \cdot \\ \cdot & \cdot & \cdot & \cdot \\ \frac{\sum_{j=1}^{40}\left(X_{j 6}-\overline{X_{6}}\right)\left(X_{j 1}-\overline{X_{1}}\right)}{40} & \frac{\sum_{j=1}^{40}\left(X_{j 6}-\overline{X_{6}}\right)\left(X_{j 2}-\overline{X_{2}}\right)}{40} & \cdots & \frac{\sum_{j=1}^{40}\left(X_{j 6}-\overline{X_{6}}\right)^{2}}{40}\end{array}\right]$

where $\bar{X}_{p}$ is the area-averaged value of $X_{p}$ for all the grid cells. Eigenvalues $\lambda_{k}$ are derived to diagonalise this cross-covariance matrix (i.e. $\boldsymbol{w}_{k}^{T} \boldsymbol{V} \boldsymbol{w}_{k}$, where $\boldsymbol{w}_{k}{ }^{T}$ is transposed matrix of $\boldsymbol{w}_{k}$.). $\lambda_{k}$ represents the variance explained by the $k$ th $\mathrm{PC}$, and its contribution ratio $C_{k}$ is calculated as:

$$
C_{k}=\frac{\lambda_{k}}{\lambda_{1}+\lambda_{2}+\lambda_{3} \ldots+\lambda_{6}}=\frac{\lambda_{k}}{\sum_{m=1}^{6} \lambda_{m}}
$$

where the total number for the $k$ th $\mathrm{PC}$ is 6 . The cumulative contribution of the $k$ th $\mathrm{PC}$ is defined as the integrated contribution from $\mathrm{PC} 1$ to the $k$ th $\mathrm{PC}$. $Z_{j k}$ is the score of the $k$ th $\mathrm{PC}$, which is calculated using Eq. (2). This score is an expression of the spatial variations of the correlations between $\mathrm{BC}$ (or BF) and the climate variables, or between $\mathrm{BC}$ (or BF) and LAI.

\section{RESULTS}

The contribution ratios of PC1 to PC3 were 41.5, 18.7 and $13.6 \%$, respectively, in the $\mathrm{BF}$ analysis, and $39.5,18.0$ and $14.1 \%$, respectively, in the BC analy- sis. The cumulative contribution of PC1 to PC3 was $73.8 \%$ for $\mathrm{BF}$ and $71.6 \%$ for BC. Therefore, the first 3 PCs explained $>70 \%$ of the observed variations of the correlations between $\mathrm{BC}$ (or $\mathrm{BF}$ ) and the climate variables, or between $\mathrm{BC}$ (or BF) and LAI.

The correlation coefficient between a PC and each independent variable (i.e. $X_{j 1-6}$ ) (Fig. 4), which is referred to as the factor loading on that $\mathrm{PC}$, can help in the interpretation of each PC. We obtained similar factor loading patterns for both BF (Fig. 4a) and BC emissions (Fig. 4b). Here we focus on the $\mathrm{BC}$ results.

PC1 represents the most prominent geographical distribution variation pattern. The 3 factor loadings on PC1 with the largest absolute values were BCtemperature (growing) (0.52), BC-temperature (dry) (0.57), and BC-precipitation (growing) $(-0.48)$. These factor loadings indicated that the $\mathrm{BC}$-temperature (growing and dry) and $\mathrm{BC}-$ precipitation (growing) correlation coefficients differed considerably in sign and magnitude among large grid cells (Fig. 3a,c,d). Therefore, PC1 reflects a large-grid-cell-specific response of $\mathrm{BC}$ emissions to variations in temperature during the growing and dry seasons and precipitation during the growing season.

(3) The 3 factor loadings on PC2 with the largest absolute values were BC-LAI (growing) (0.49), BCprecipitation (growing) (0.54) and $\mathrm{BC}$-cloud cover (growing) (-0.56). These factor loadings showed that the correlation coefficients $\mathrm{BC}$-precipitation (growing), BC-LAI (growing) and BC-cloud cover (growing) differed slightly in sign or magnitude among large grid cells (Fig. 3c,e,f). Therefore, PC2 reflects a large-grid-cell-specific response of $\mathrm{BC}$ emissions to variations in precipitation, cloud cover and LAI during the growing season.

The factor loadings on PC3 with the 3 largest absolute values were BC-LAI (growing) (0.67), BCtemperature (dry) (-0.54) and BC-cloud cover (dry) (0.39). These factor loadings showed that the correlation coefficients for BC-LAI (growing), BC-cloud cover (dry) and BC-temperature (dry) differed slightly in sign or magnitude among large grid cells (Fig. 3a,b,f). Therefore, PC3 reflects a large-grid-cellspecific response of $\mathrm{BC}$ emissions to variations in temperature and cloud cover during the dry season and LAI in the growing season.

The PCs were normalised to unit variance. The spatial variations of the correlations between $\mathrm{BC}$ and the climate variables, or between BC and LAI, across the grid cells of PC2 and PC3 were small compared with those of PC1 because these variations became small in turn compared with PC1. There was a pattern of opposite correlations be- 

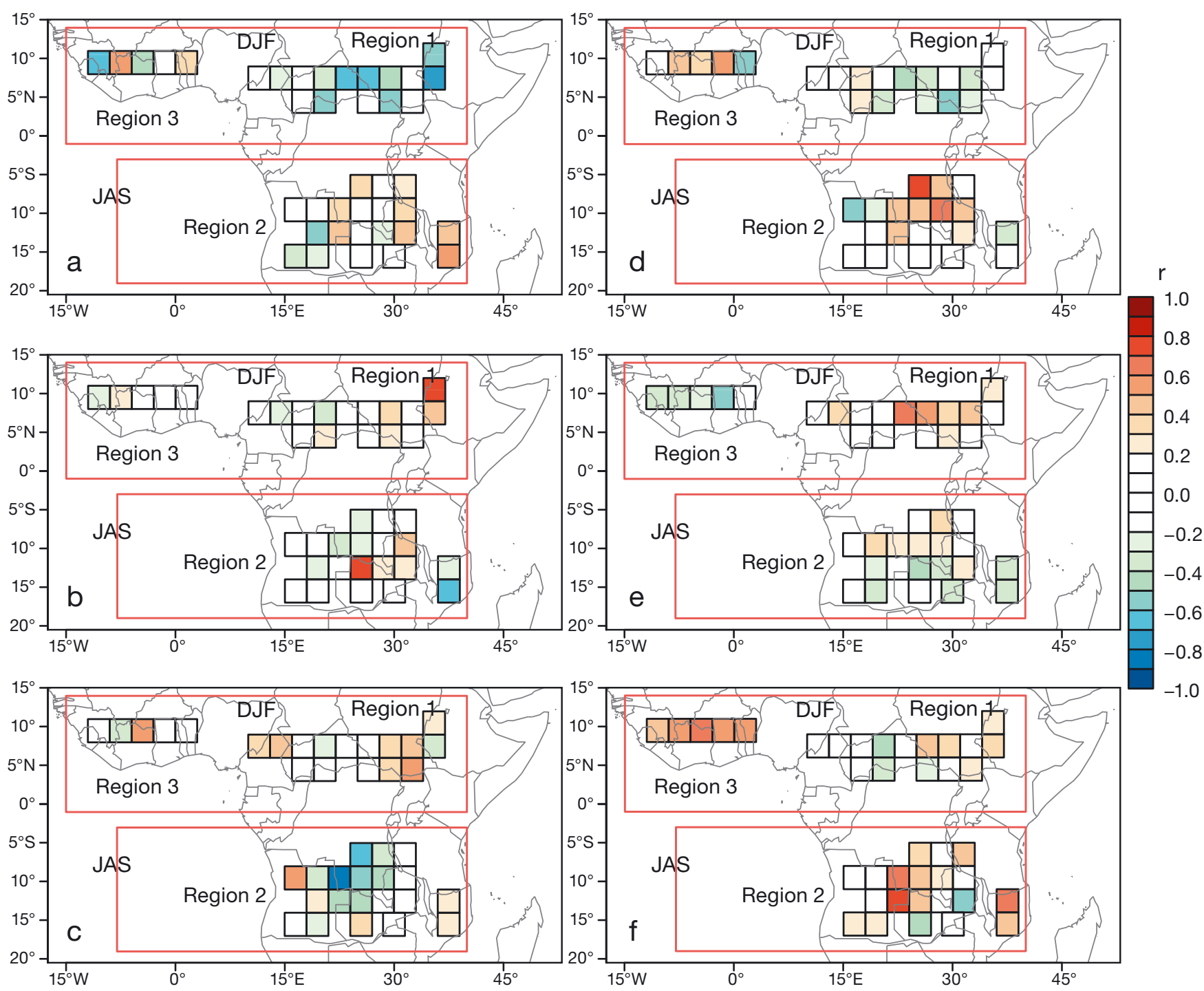

Fig. 3. Correlation coefficient (r) between black carbon (BC) and (a) dry season temperature, (b) dry season cloud cover, (c) growing season precipitation, (d) growing season temperature, (e) growing season cloud cover, (f) growing season leaf area index during 1997-2008. DJF: December to February; JAS: July to September

tween $\mathrm{BC}$ and climate among the grid cells with different signs and large scores. The $\mathrm{PC} 2$ and $\mathrm{PC} 3$ scores can be interpreted in the same way. However, the geographical patterns of contrary correlations of $\mathrm{BC}$ with climate or the plant parameters of PC2 and PC3 were smaller than those of PC1. It is difficult to make meaningful comparisons with the patterns of variation in the geographical distribution of the correlation coefficients across the grid cells of PC3 because the characteristic geographical distribution pattern of the PC3 score is unclear. Therefore, we focused on PC1 and PC2.

The average PC1 score in Region 1 was -0.43 , which indicates that the $\mathrm{BC}$ emission rate increased as temperature decreased and precipitation increased. In Regions 2 and 3, the average PC1 scores were 0.26 and 0.27 , respectively, indicating that the $\mathrm{BC}$ emission rate increased with temperature and decreased with precipitation (Fig. 5a).

The average PC2 score in Region 3 was 0.36 , indicating that the $\mathrm{BC}$ emission rate increased slightly with precipitation and LAI, and decreased with cloud cover. In contrast, in part of Region $1\left(9-3^{\circ} \mathrm{N}, 16-\right.$ $25^{\circ} \mathrm{E}$ ), the average PC2 score was -0.47 , and it was -0.16 in part of Region $2\left(8-15^{\circ} \mathrm{S}, 15-33^{\circ} \mathrm{E}\right)$. These scores indicate that the $\mathrm{BC}$ emission rate increased slightly as the precipitation and LAI decreased, and increased with cloud cover in these areas (Fig. 5b). 


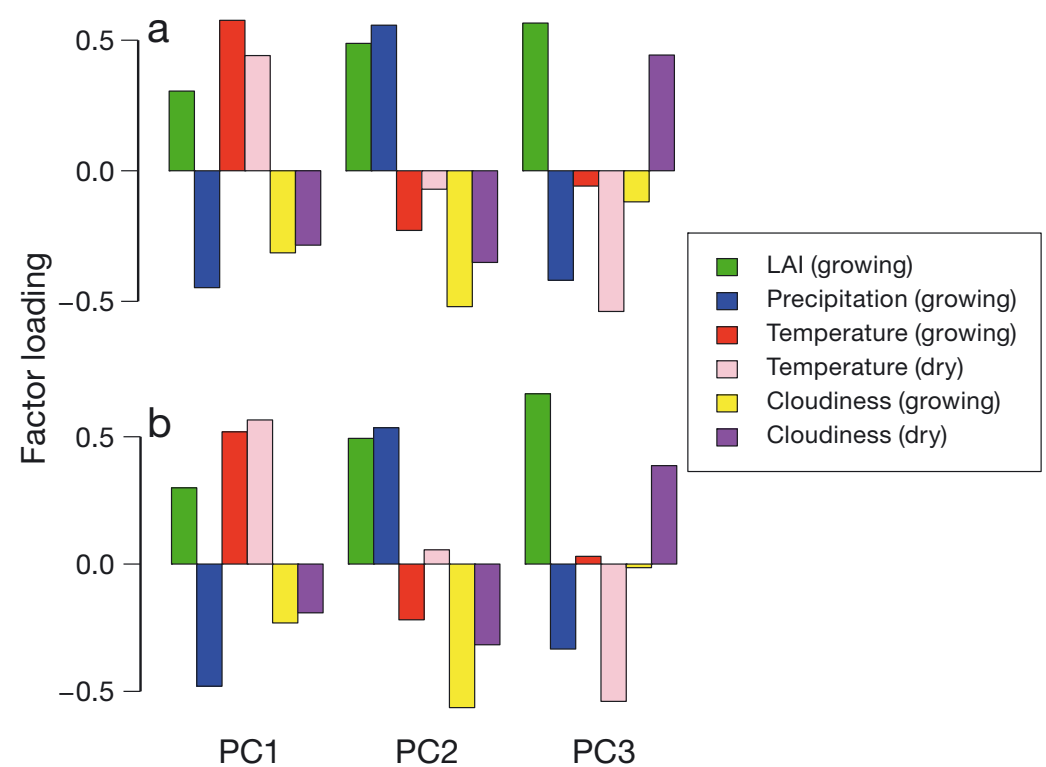

Fig. 4. Factor loadings on principal components (PCs) 1-3: (a) burned fraction $(\mathrm{BF})$ and (b) black carbon (BC) emission. A large absolute value means that the factor strongly affects $\mathrm{BF}$ or $\mathrm{BC}$. The sign of the factor loading corresponds to the sign of the correlation coefficient between $\mathrm{BF}$ (or $\mathrm{BC}$ ) and the respective variable. LAI: leaf area index
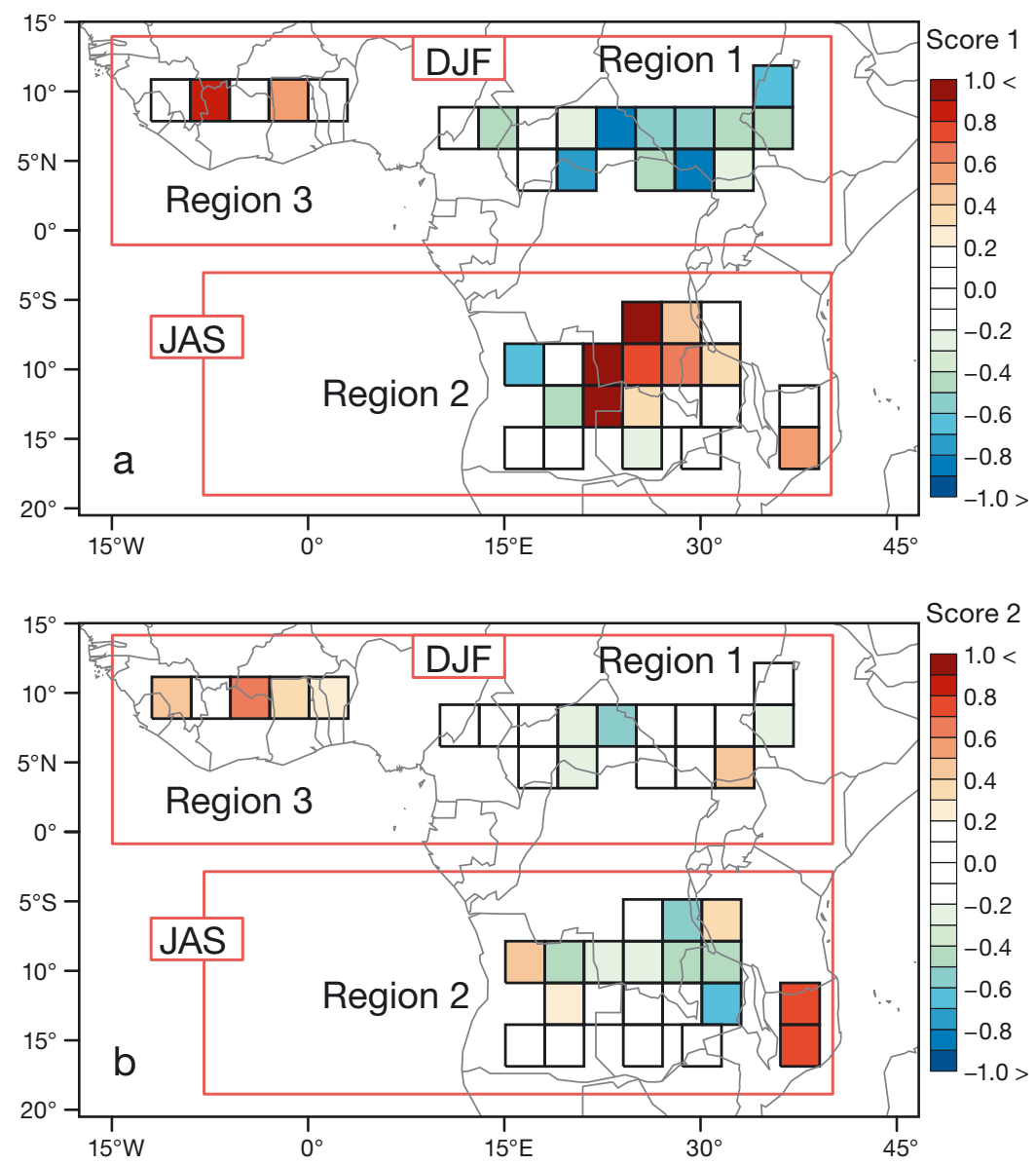

\section{DISCUSSION}

The factor loadings on each PC and the PC scores were similar for $\mathrm{BC}$ emission and the BF (Fig. 4). In the Global Fire Emission Database (Table 1), BC emissions were estimated from 3 variables: the BC emission factor, the burned area and the dry matter mass (see the Appendix). The burned area and dry matter mass changed with time, but the BC emission factor did not. The interannual differences in $\mathrm{BC}$ emission should depend strongly on the burned area and the available dry matter mass. The BF is calculated from the burned area, so it is not surprising that in our results, the geographical distribution patterns were similar between $\mathrm{BC}$ emissions (i.e. the factor loadings and the PC scores) and the BF.

Higher vegetation productivity would result in a larger fuel load and a larger burned area, and hence more BC emission. However, temperature and precipitation during the growing season were negatively correlated in most large grid cells (Fig. 6). This means that the BC-precipitation and BC-temperature correlation coefficients had opposite signs in each large grid cell (Fig. 3c,d). Therefore, the factor loadings of $\mathrm{BC}$-temperature (growing and dry) and BC-precipitation (growing) on PC1 had opposite signs. The correlation coefficient between growingand dry-season temperature was positive in nearly all large grid cells (Fig. 7) because the tendency of the growthseason temperature carried over to the dry-season temperature. As a result, the factor loading of $\mathrm{BC}$-temperature (dry) on PC1 was large.

Fig. 5. Principal component (PC) scores in each large grid cell during the dry season obtained in the black carbon (BC) analysis: (a) PC1 and (b) PC2. Positive scores (warm colours) indicate the same tendency as the factor loadings on that $\mathrm{PC}$, and negative scores (cool colours) indicate the opposite tendency to the factor loadings. DJF: December to February; JAS: July to September 


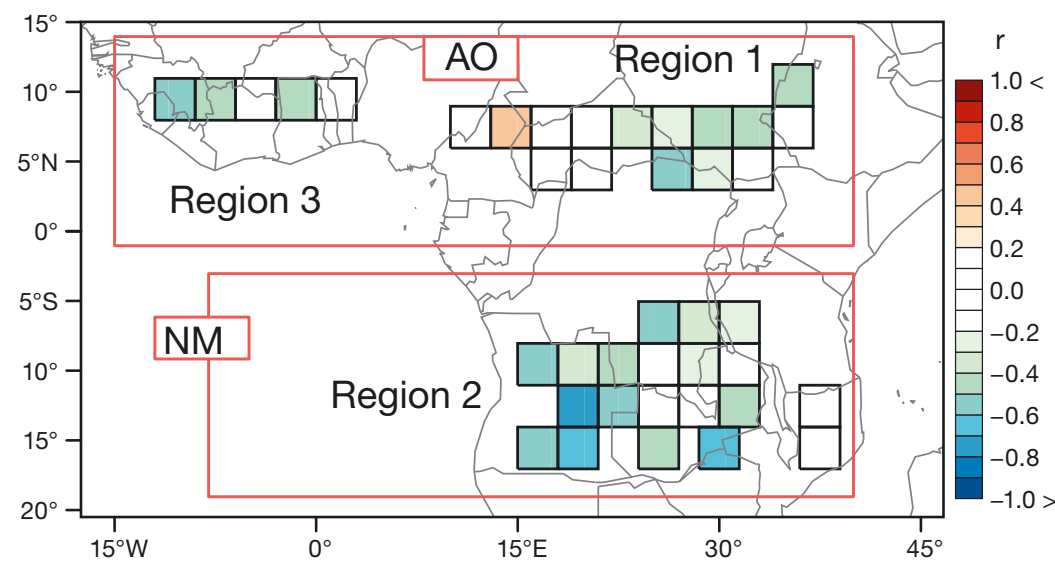

Fig. 6. Correlation coefficients between precipitation and temperature during the growing season during 1997-2008. AO: August to October; NM: November to May

We interpreted PC1 as the response pattern of vegetation productivity to temperature and precipitation during the growing season. The geographical distribution pattern of PC1 depended greatly on the geographical distribution of biomes (Fig. 8). In Region 1, the dominant biome is savannah throughout. The northern part of Region 2 is dominated by tropical deciduous forest, and the southern part is dominated by savannah. Both tropical evergreen forest and savannah are also found in Region 3. The PC1 scores differed among these 3 biome types (Fig. 9). In the savannah, $68 \%$ of the large grid cells had negative PC1 scores, and $67 \%$ of the large grid cells in tropical deciduous and evergreen forest had positive PC1 scores. This indicates that the $\mathrm{BC}$ emission rate increased with the growing-season precipitation in the savannah and the growing-season temperature in tropical deciduous and evergreen forests. Hickler et al. (2005) and Anyamba \& Tucker (2005) showed that

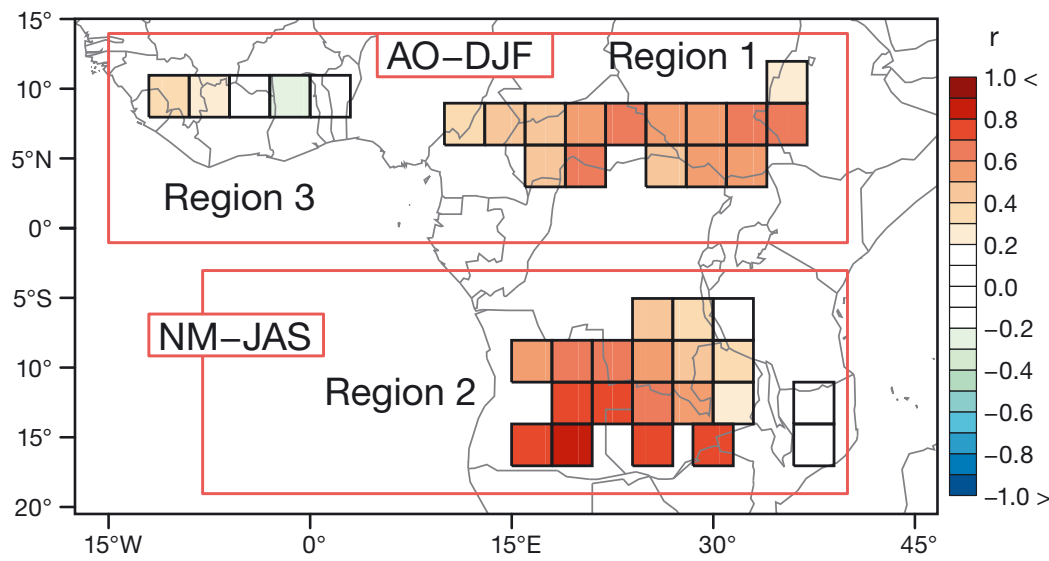

Fig. 7. Correlation coefficients for temperature between the growing and dry seasons during 1997-2008. AO: August to October; DJF: December to February; NM: November to May; JAS: July to September in semi-arid regions with abundant herbaceous species, NDVI and LAI are sensitive to precipitation changes. In contrast, in forested regions, Allen et al. (2010) showed that vegetation productivity is more affected by temperature and solar radiation than by precipitation. These differing dependencies of vegetation production among the biomes would explain the differentiation in the sign of PC1.

PC2 can be more intuitively understood if the factor loading of $\mathrm{BC}-$ cloud cover ( growing) on PC2 is compared with that of BC-Sd ( growing), where $\mathrm{Sd}$ indicates the intensity of the downward shortwave radiation. Sd is inversely correlated with cloud cover, so the correlation coefficients for BC-cloud cover (growing) and BC-Sd ( growing) should have opposite signs.

In large grid cells with positive PC2 scores, LAI increased in years with more precipitation, and Sd was higher during the growing season. This suggests that both the $\mathrm{BC}$ emission rate and the burned area increased during years of higher vegetation productivity. We therefore interpret positive PC2 scores as the response patterns of vegetation productivity (i.e. the fuel-loading response pattern) to precipitation and Sd during the growing season.

In contrast, in large grid cells with negative PC2 scores, the $\mathrm{BC}$ emission rate either increased or showed no relation to decreases in precipitation, $\mathrm{Sd}$ and LAI during the growing season. Archibald et al. (2009) and Bond et al. (2003) explained the smaller burned areas in regions with higher tree cover as follows. Higher tree cover reduces the intensity of sunlight reaching the forest floor, thus hindering the growth of grass. Furthermore, the ignition frequency is reduced because grass and litter on the forest floor are prevented from drying out, and wildfires do not spread. Archibald et al. (2009) and Scholes (2003) suggested that wildfires rarely occur when the tree cover exceeds about $40 \%$. We compared the PC2 scores for tree cover and LAI with PC2 scores in some subsets of large grid cells (Fig. 10). The mean $\pm \mathrm{SD}$ tree cover was $42.4 \pm 5.5 \%$, and the average LAI was $2.2 \pm 0.5 \mathrm{~m}^{2} \mathrm{~m}^{-2}$ in large grid cells with $\mathrm{PC} 2$ scores lower than -0.2. Therefore, in large grid 


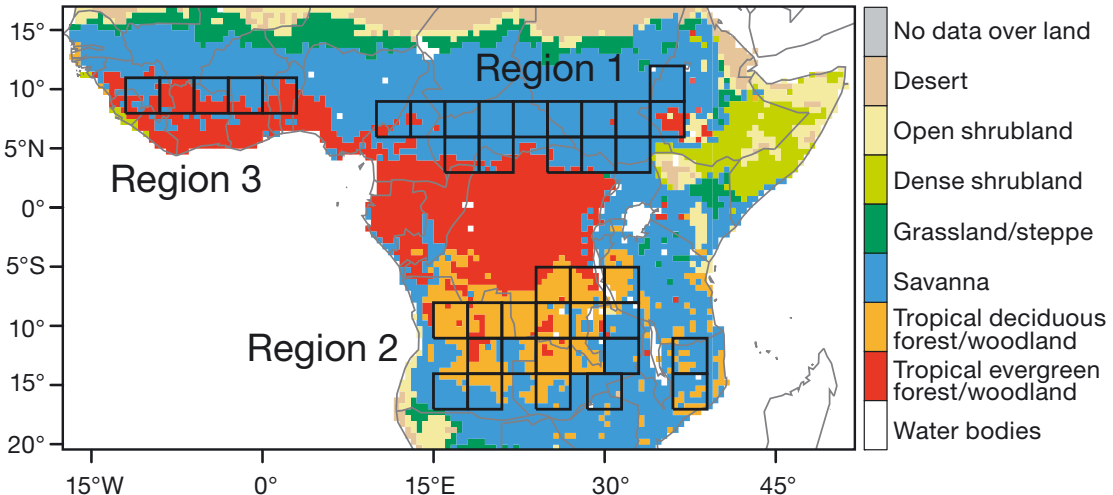

Fig. 8. Biome distributions in central Africa

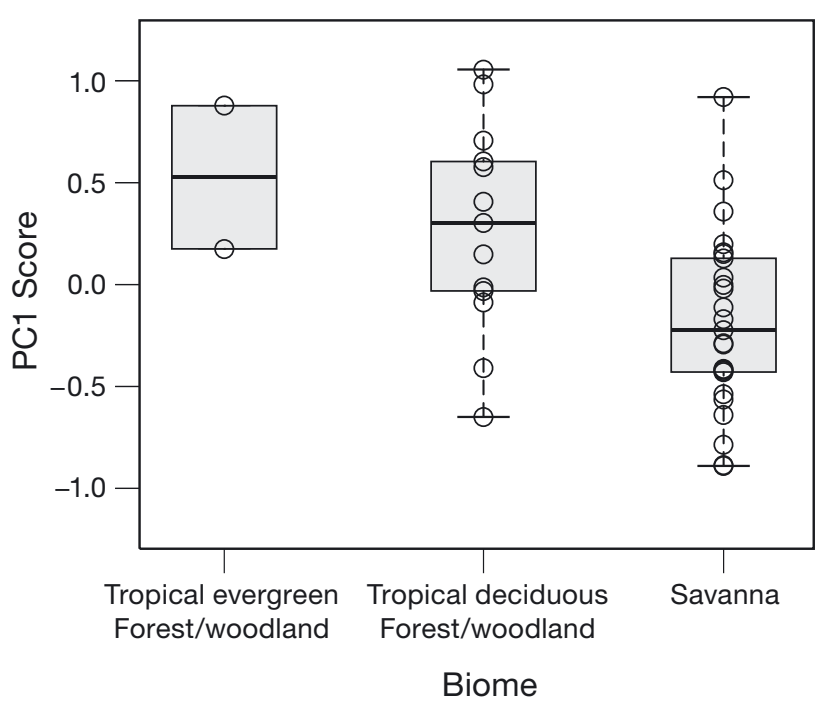

Fig. 9. Principal component 1 (PC1) scores averaged by biome type. Circles: PC1 score in each grid cell classified into a biome type; bottom and top of each box: lower and upper quartiles, respectively; bold horizontal line in the middle of the box: median value

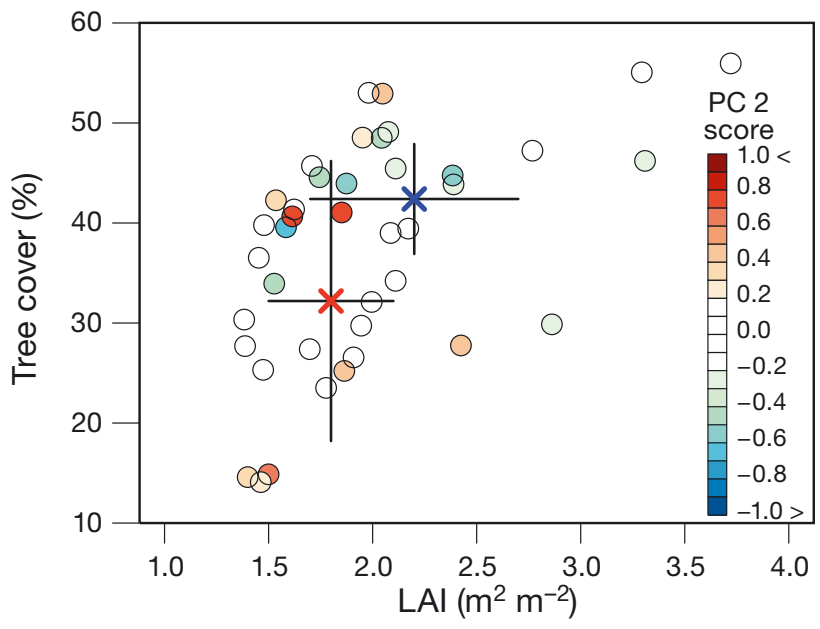

cells with negative scores, lower precipitation and $\mathrm{Sd}$ reduced the tree cover and increased the burned area, increasing $\mathrm{BC}$ emissions.

\section{CONCLUSION}

We used PCA to extract factors accounting for the spatial variations of the correlations between $\mathrm{BC}$ and the climate variables, or between $\mathrm{BC}$ and LAI. We interpreted PC1 (contribution ratio, $39.5 \%$ ) as mainly reflecting the response of vegetation productivity to temperature and precipitation during the growing season. This pattern is regulated primarily by biome type. We interpreted PC2 (contribution ratio, 18.0\%) as a geographical distribution pattern primarily regulated by tree cover, which in turn regulates the abundance of herbaceous vegetation. The cumulative contribution ratio of the vegetation productivity response (57.5\%; PC1 and PC2) was much higher than the contribution ratio of climate variables in the dry season $(14.1 \%$; PC3). From these findings, we concluded that the spatial variations of the correlations between $\mathrm{BC}$ and the climate variables, or between BC and LAI, primarily reflect biome type and tree cover, both of which differed considerably among the 3 regions studied.

The geographical distribution patterns of BC emissions may change if the distribution of vegetation types changes under future climate change in Africa. Therefore, future studies should examine the impact of predicted changes in vegetation and biome distributions on BC emission patterns and how, in turn, BC emission pattern changes are likely to affect future climate.

Acknowledgements. We thank 2 anonymous reviewers for their constructive comments. This work was financially supported by the Tohoku University Global Center of Excellence programme 'Global Education and Research Center for Earth and Planetary Dynamics'.

Fig. 10. Relationships among the principal component 2 (PC2) scores (colour scale), tree cover and leaf area index (LAI). The average for grid cells with scores smaller than -0.2 is shown by a blue $X$, and the average for grid cells with scores larger than +0.2 is shown by a red $X$. The standard deviations of tree cover and LAI are respectively shown by the vertical and horizontal gray lines passing through each average 


\section{LITERATURE CITED}

Allen CD, Macalady AK, Chenchouni H, Bachelet D and others (2010) A global overview of drought and heatinduced tree mortality reveals emerging climate change risks for forests. For Ecol Manag 259:660-684

Anyamba A, Tucker C (2005) Analysis of Sahelian vegetation dynamics using NOAA-AVHRR NDVI data from 1981-2003. J Arid Environ 63:596-614

> Archibald S, Roy DP, van Wilgen BW, Scholes RJ (2009) What limits fire? An examination of drivers of burnt area in Southern Africa. Glob Change Biol 15:613-630

> Bond WJ, Midgley GF, Woodward FI (2003) The importance of low atmospheric $\mathrm{CO}_{2}$ and fire in promoting the spread of grasslands and savannas. Glob Change Biol 9:973-982

Bond TC, Streets DG, Yarber KF, Nelson SM, Woo JH, Klimont Z (2004) A technology-based global inventory of black and organic carbon emissions from combustion. J Geophys Res 109:D14203, doi:10.1029/2003JD003697

$>$ Bond WJ, Woodward FI, Midgley GF (2005) The global distribution of ecosystems in a world without fire. New Phytol 165:525-537

> Bowman DM, Balch JK, Artaxo P, Bond WJ and others (2009) Fire in the Earth system. Science 324:481-484

> Cooke WF, Koffi B, Gregoire JM (1996) Seasonality of vegetation fires in Africa from remote sensing data and application to a global chemistry model. Geophys Res Lett 101:21051-21065

DeFries R, Hansen M, Townshend JRG, Janetos AC, Loveland TR (2000) A new global 1-km data set of percent tree cover derived from remote sensing. Glob Change Biol 6:247-254

> Dwyer E, Pinnock S, Grègoire JM, Pereira JMC (2000) Global spatial and temporal distribution of vegetation fire as determined from satellite observations. Int J Remote Sens 21:1289-1302

Giglio L, Randerson J, van der Werf G, Kasibhatla P, Collatz G, Morton D, DeFries R (2010) Assessing variability and long-term trends in burned area by merging multiple satellite fire products. Biogeosciences 7:1171-1186

Gonzalez P (2001) Desertification and a shift of forest species in the West African Sahel. Clim Res 17:217-228

> Hickler T, Eklundh L, Seaquist J, Smith B and others (2005) Precipitation controls Sahel greening trend. Geophys Res Lett 32:L21415, doi:10.1029/2005GL024370

> Higgins SI, Bond WJ, Trollope WSW (2000) Fire, resprouting and variability: a recipe for grass-tree coexistence in savanna. J Ecol 88:213-229

Higgins SI, Bond WJ, February EC, Bronn A and others (2007) Effects of four decades of fire manipulation on woody vegetation structure in savanna. Ecology 88:1119-1125

Hui D, Jackson RB (2006) Geographical and inter-annual variability in biomass partitioning in grassland ecosystems: a synthesis of field data. New Phytol 169:85-93
Kawase H, Takemura T, Nozawa T (2011) Impact of carbonaceous aerosols on precipitation in tropical Africa during the austral summer in the twentieth century. Geophys Res Lett 116:D18116, doi:10.1029/2011JD015933

Keeley JE, Fotheringham CJ, Morais M (1999) Reexamining fire suppression impacts on brushland fire regimes. Science 284:1829-1832

Lehsten V, Tansey $\mathrm{K}$, Balzter $\mathrm{H}$, Thonicke $\mathrm{K}$ and others (2009) Estimating carbon emissions from African wildfires. Biogeosciences 6:349-360

Lwanga JS (2003) Localized tree mortality following the drought of 1999 at Ngogo, Kibale National Park, Uganda. Afr J Ecol 41:194-196

MacGregor SD, O'Connor TG (2002) Patch dieback of Colophospermum mopane in a dysfunctional semi-arid African savanna. Austral Ecol 27:385-395

> Mitchell TD, Jones PD (2005) An improved method of constructing a database of monthly climate observations and associated high-resolution grids. Int $\mathrm{J}$ Climatol 25: 693-712

> Ramanathan V, Carmichael G (2008) Global and regional climate changes due to black carbon. Nat Geosci 1: 221-227

Russell-Smith J, Yates CP, Whitehead PJ, Smith R and others (2007) Bushfires 'down under': patterns and implications of contemporary Australian landscape burning. Int J Wildland Fire 16:361-377

> Sankaran M, Ratnam J, Hanan NP (2004) Tree-grass coexistence in savannas revisited - insights from an examination of assumptions and mechanisms invoked in existing models. Ecol Lett 7:480-490

> Sankaran M, Hanan NP, Scholes RJ, Ratnam J and others (2005) Determinants of woody cover in African savannas. Nature 438:846-849

Schmidt MWI, Skjemstad JO, Czimczik CI, Glaser B, Prentice KM, Gelinas Y, Kuhlbusch TK (2001) Comparative analysis of black carbon in soils. Global Biogeochem Cycles 15:163-167

Scholes RJ (2003) Convex relationships in ecosystems containing mixtures of trees and grass. Environ Resour Econ 26:559-574

Turner DP, WD Ritts, M Gregory (2006) BigFoot NPP surfaces for North and South American sites, 2002-2004. Oak Ridge National Laboratory Distributed Active Archive Center, Oak Ridge, TN. http://daac.ornl.gov/cgi-bin/ dsviewer.pl?ds_id=750, doi:10.3334/ORNLDAAC/750

van der Ent RJ, Savenije HHG, Schaefli B, Steele-Dunne SC (2010) Origin and fate of atmospheric moisture over continents. Water Resour Res 46:W09525, doi:10.1029/2010 WR009127

> van der Werf GR, Randerson JT, Giglio L, Collatz GJ and others (2010) Global fire emissions and the contribution of deforestation, savanna, forest, agricultural, and peat fires (1997-2009). Atmos Chem Phys 10:11707-11735 


\section{Appendix}

In the Global Fire Emissions Database v. 3, BC emissions were estimated by computing 3 variables: burned area, dry matter and the $\mathrm{BC}$ emission factor, which depends on the biome type. First, the burned area $A(i, t)$ in each $0.5^{\circ} \times 0.5^{\circ}$ grid cell was estimated using a non-linear function of the number of active fires in a month, $N_{\mathrm{f}}(i, t)$, as

$$
A(i, t)=\alpha(i) N_{\mathrm{f}}(i, t)^{\beta(i)}
$$

where $i$ is the grid cell, $t$ is the month, and $\alpha(i) \geq 0$ (Giglio et al. 2010). The parameters $\alpha$ and $\beta$ were estimated independently in each grid cell. Second, the dry matter mass was estimated from the living biomass pool size by use of the allocation scheme (Hui \& Jackson 2006), which was derived from the net primary productivity (NPP). NPP was derived from satellite remote sensing data as

$$
\operatorname{NPP}(i, t)=\operatorname{fAPAR}(i, t) \times \operatorname{PAR}(i, t) \times \varepsilon(T, P)
$$

where $\operatorname{PAR}(i, t)$ is the photosynthetically active radiation, $\operatorname{fAPAR}(i, t)$ is the fraction of available PAR absorbed by vegetation, $\varepsilon(T, P)$ is the maximum light use efficiency, $T$ is temperature, and $P$ is moisture. Third, the $\mathrm{BC}$ emission was computed by multiplying the dry matter mass burned, which was derived from Eq. (A1) and the dry matter, by its emission factor ( $\mathrm{g} \mathrm{BC}$ $\mathrm{kg}^{-1}$ dry matter mass burned), which depends on the biome (van der Werf et al. 2010). The results of a Monte Carlo simulation indicated that globally, uncertainties were around $20 \%(1 \sigma)$ for annual BC estimates during 2001-2009. The uncertainties for Africa (both northern and southern hemisphere regions) were of the same magnitude (van der Werf et al. 2010).

Editorial responsibility: Gerd Esser, Gießen, Germany
Submitted: December 20, 2012; Accepted: June 24, 2013 Proofs received from author(s): October 5, 2013 